就, T. owuensis, T. teramurai, T. intermedia, T. palpalis, T. nagayoi はその南限は種により暴るが，北湤; 道，東北地方，関東・中部地方の山岳地带にとれてい る。この中例党ば T. intermedia 甠北海道で法原野に とれ，中部地方で汕岳でとれるというように生物分布 に上く东られる水平分布の北方のものが，より符方の韭 政分有の高地にあるとも認めら扎た。南西地方の種 は, T. tanaka-ryoi, T. (Trombiculindus) kansai, $T$. kutroshio, T. daisen, T. (Miyatrombicuir) kochiensis

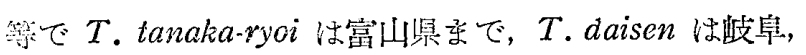

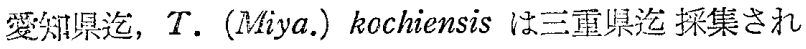
ている、ヒミズモグラ汇等生する T. yasuokai, T. miyairii, Doloisia okabei, Shunsenia tarsalis 国汇だけ知られている，T. wichimanni は八父島で採

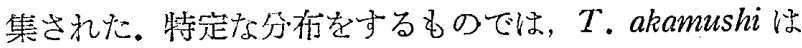

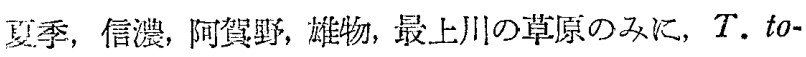

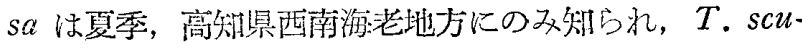
iellaris は冬季に山形，新舄県で嘗より知られていたが，

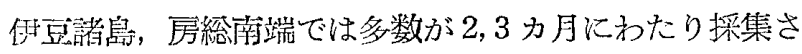

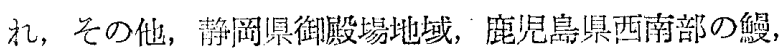

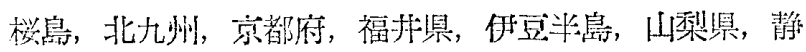

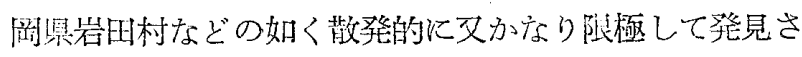
れ，北方程発生が早く，留現している期間が哣い上らで 当。。

【伀研等生蝁]

\section{誥の虫緒方 湿雄}

Ogata, N.: Tsutsuganomushi

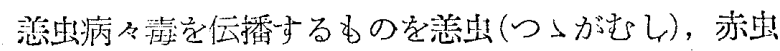

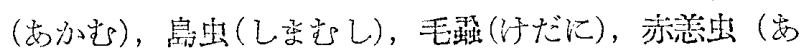

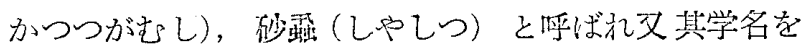
Trombicula akamushi Brumpt 1910, Kedania tanakai Kishida そ称世られているが，菭い月本の文献には恙山

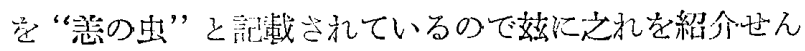
とするるので岁る。最近をで吾々は恙虫病及び意虫に就 て最古の文剈と して Baelz, E. in Verbindung mit Stud. med. Kawakami: Das japanische Fluss-oder Überschwemmungsfieber, eine Acute Infektionskrankheit. Virchow's Archiv Bd. IXXVIII, Heft 3, 373 〜420，1879(明治 12 年)を挙げていた。而して此の論交 の内には恙出を Tsutsugamushi, Akamushi, Shima-

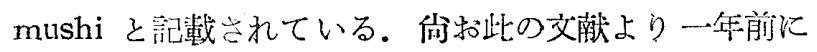
英国で発表せられているものに Palm, T. A.： Some
Accant of a disease called Shimamushi or Island Insekt-Desease by the natives of Japan. Edinborongh med. J. 1878(明治 11 年) Vol, 24. がある。其の内には

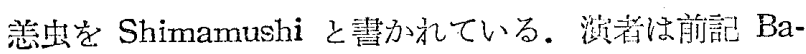
elz und Kawakami の川上に就て其の消息学知らんと して, 明治 10 年 13 年に至る 東京医事新誌（本誌は明 治 10 年 2 月 25 日創刊) を涉悦した所， Baelz 不び PaIm の文解より更化古き日本人学徒による贵重なる数論 交を見附けたのでをれを全部復写して置いた。

○梛野直 : 陸軍本病院錄寒 (明治十年十二月附) 柬京医

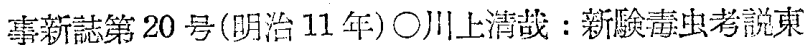
京医帚新誌第 20 号及び 21 昂 (明治 11 年) 0 大学医学部 内科教枯ベルッ氏自費觉以て恙の出調查のため越後国

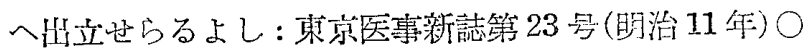
梛野直：恙虫研究病院報告摘要：東京医專新誌第 44 号

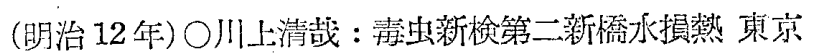
医事新誌第 51 号 (明治12年) ○小池正直 : 恙光虫 東京医 事新誌第 95 号 10 頁 (明治 13 年) 以上梛野以下の論文に は恙虫の代的りに恙/出页出恙之虫之記載されている。 勿論此の外飞島岳，赤虫とも記载されている，上記棚野 川上雨氏の論文を通読すると意虫病の臨床及び病理に於 て今日之れに改訂を要する点を見出し得ない程完成せる もので，彼の Baelz の論文は河氏の諭文内容の独訳汇 過ぎない感がする。朷諭病原に就きては Malaria に泛

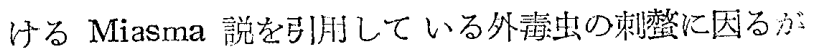
附图に描写してある如く赫虫出を区別している。方れ を今日の知見から見机ば前者は三文脚, 後者は四対脚で

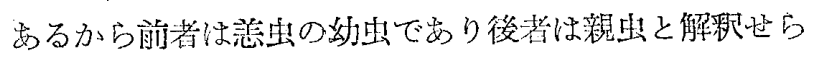
る可きもので忠る。装するに恙虫病及び恙出に関する文 献は Baelz のものより占く面も日本学徒により詳細化 調査されたる報告には敬意を表する外，“恙の出”を基 雷して Trombicula tsutsuganomushi-Ricketisia tsutsu-

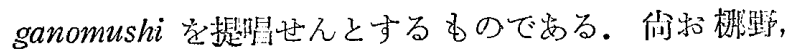
川上两氏の論文は拙薪（緒厅想焳：日本恙虫病研究七十 七年史乘京医事新誌第 70 巻 10 号昭和 28 年) を参照呫占 れたし。

[来邦大細菌] 